\title{
卓上型運動錯覚誘発・評価装置の開発
}

\author{
本多 正計*1，唐川 裕之 ${ }^{* 2}$ ，赤堀 晃一 ${ }^{*} 3$ ，宮岡 徹*4，大岡 昌博 ${ }^{*}$
}

\section{Development of a desktop inducing and evaluation system of kinesthetic illusion}

\author{
Masakazu HONDA $^{* 1}$, Hiroyuki KARAKAWA ${ }^{* 2}$, Koichi AKAHORI ${ }^{* 3}$, Tetsu MIYAOKA ${ }^{* 4}$ and \\ Masahiro OHKA ${ }^{* 5}$ \\ ${ }^{* 1}$ Industrial Research Institute of Shizuoka Prefecture \\ 3981-1 Oooka, Numazu-shi, Shizuoka 410-0022, Japan \\ ${ }^{* 2}$ Graduate School of Information Science, Nagoya University \\ Furo-cho, Chikusa-ku, Nagoya 464-8601, Japan \\ ${ }^{* 3}$ Graduate School of Engineering, Nagoya University \\ Furo-cho, Chikusa-ku, Nagoya 464-8601, Japan \\ ${ }^{* 4}$ Shizuoka Institute of Science and Technology \\ 2200-2 Toyosawa, Fukuroi-shi, Shizuoka 437-8555, Japan \\ ${ }^{* 5}$ Nagoya University \\ Furo-cho, Chikusa-ku, Nagoya 464-8601, Japan
}

\section{Received 23 June 2014}

\begin{abstract}
Since our ultimate target is to realize a simple and inexpensive rehabilitation system of kinesthetic illusion and apply it to rehabilitation training, we need to miniaturize the vibration stimulus device and systematize the vibration stimulus conditions to freely induce and control the illusion. In this paper, we developed a desktop kinesthetic illusion inducement and evaluation system that allows us to investigate the sensory properties of the illusion. When the contact force of a contact head is under $1.5 \mathrm{~N}$, our system can apply vibration stimuli of $100 \mathrm{~m} / \mathrm{s}^{2}$ to the tendon between 50 and $300 \mathrm{~Hz}$. Experiments with this system induced kinesthetic illusion of an extension at the right hand joint in all five subjects. We confirmed the efficacy of an estimation system of sensory properties and enhanced gatherings of the vibration stimulus conditions to induce and control the illusion.
\end{abstract}

Key words : Kinesthetic illusion, Neuro-rehabilitation, System design, Stimulation threshold, Hemiplegic stroke

\section{1. 緒言}

日本人の死亡原因第三位である脳卒中は，有効な治療法の登場，脳卒中専門病棟の整備などにより，死亡者数 は減少傾向（2012 年 121602 人）(厚生労働省 H24 人口動態調査, 2012) にある. しかし，総患者数は年々増加し ており（2011 年 1235 千人）(厚生労働省, H23 患者調査, 2011 ), 2020 年には 300 万人を突破すると予想されてい る.このことは, 罹患して生き残る方が増えることを意味しているが, これが次の新しい問題を生みだしている.

脳卒中を発症すると麻痺等の運動障害が発生する。これら障害は，適切なリハビリテーション（運動機能訓練 など）を実施することで，発症後 6 か月位までは急速に回復するが，それ以降は慢性期と呼ばれ回復しにくくな り，発症者の約 6 割の人が後遺症に苦しんでいる。しかし，最近の脳科学の発展により，脳の可塑性が従来の定 説よりはるかに大きく短期間で生じることが明らかにされ，大脳皮質の運動を司る領域の神経路を再建/強化（刺 激）させることで，6か月を過ぎでも運動機能の回復が望めることが確認されてきた (原, 2012).

\footnotetext{
No. 14-00335 [DOI: 10.1299/transjsme.2014trans0350]

*1 静岡県工業技術研究所（广410-0022 静岡県沼津市大岡 3981-1）

*2 名古屋大学大学院 情報科学研究科（一464-8601 愛知県名古屋市千種区不老町） (現 (株) 中央製作所)

*3 名古屋大学大学院 工学研究科

*4 静岡理工科大学 総合情報学部（干437-8555 静岡県袋井市豊沢 2200-2）

*5 正員, 名古屋大学

E-mail of corresponding author: honda@iri.pref.shizuoka.jp
} 
近年では，脳の可塑性に注目したリハビリテーション（ニューロリハビリテーション）として，反復促通療法 (Kawahira, et al., 2004)，CI 療法 (Wolf, et al.,1989), HANDS 療法 (Fujiwara, et al., 2009) といった新しい療法が提唱 されており一定の治療効果を上げている，麻痺回復のためのリハビリテーションの効果をさらに引き上げるため には，このような科学的根拠に基づいた療法を数多く提唱し，それらを治療法として手軽に受けられる環境を患 者に提供することが重要であると考える.そのためには, 新しい療法に精通した療法士の育成はもちろんのこと, 患者一人でも手軽に訓練に励めるようなリハビリテーション機器の開発も必要となる，そこで我々は，運動を司 る領域の神経路を同じく興奮させることができる運動錯覚 (Goodwin, et al., 1972) という現象に着目し, 同現象を 応用したシンプルで安価なリハビリテーションシステムの開発を目指している.

運動錯覚とは，動いていない四肢があたかも動いているかのように感じられる，実際の運動と知覚される運動 の間に不一致が生じる現象であり, 1972 年 Goodwin らによって初めて報告された運動感覚の錯覚現象である. こ の現象は, ヒトの運動感覚に関する感覚情報処理研究の中で多く活用されてきており,これまでの研究によって, 錯覚中に活動する脳部位が, 実際に四肢等を動かす時に活動する部位と同じであることがわかっている (Naito, et al., 1999) 。また，軽度な感覚障害であれば，脳卒中片麻痺患者においても錯覚が誘発されることが確認されてい る (湯川他, 2012). このことは, 脳卒中片麻痺患者においても運動錯覚を誘発させることでダメ一ジを負った大 脳皮質運動野等を刺激できるため, 脳の可塑的変化を促せる可能性を示唆しており, リハビリテーション治療へ の応用が期待できる.また運動錯覚は, 皮膚上から腱に振動刺激を与えるだけで誘発できるため, 研究の進展に よっては，小型の振動提示デバイスを利用して，麻瘏肢の腱上の皮膚にそれらのデバイスを貼り付けるだけで運 動機能訓練が行える小型で簡易なシステムの実現が期待される.

しかし現状では，振動刺激に対する運動錯覚現象の詳細な知覚特性がわかっていないため, 振動提示デバイス の基本仕様も定まっておらず，小型振動提示デバイスの開発はおろか，運動機能訓練時に必要となる動きの感覚 についても，その質や量を自在に誘発・制御させることが難しい状況にある．そのため，上述のシステムを実現 させるためには, まず, 同現象の知覚特性を詳細に調べ, 錯覚現象の自在な誘発と制御を可能とする振動刺激条 件の確立と体系化が必要不可欠である.

そこで本研究では，運動錯覚に関する知覚特性を調べるうえで必要となる，振動刺激量の制御とモニタリング が可能な, 卓上型運動錯覚誘発・評価装置を提案・開発し, その基本性能を明らかにするとともに, 同開発装置 を用いて健常者の右手手関節伸展運動の錯覚誘発刺激閾值の推定を試みる. これにより, 同装置の知覚特性評価 装置としての有効性を確認するとともに，錯覚を誘発・制御させるための振動刺激条件の蓄積を図る．なお，前 述のように，軽度の症例であれば脳卒中片麻瘏患者も運動錯覚を知覚することが可能であるが，正常な動きの錯 覚を誘発させるための刺激条件を得るための実験の実施・解析の容易性を勘案して, 本実験では健常者を実験の 対象としている.

\section{2. 運動錯覚誘発・評価装置}

本章では, 卓上型の運動錯覚誘発・評価装置を実現させるための一連の設計手順について述べる. 本研究開発 ではまず始めに, 錯覚を誘発させるための部位を選定し, その部位の運動錯覚を誘発可能な卓上型運動錯覚誘発・ 評価装置の基本設計を行った，次に詳細設計として，装置の具体的なデザインおよび各部の寸法を決定した．最 後に，これら設計内容を基に実用レベルの装置を開発した，以下では，各設計フェーズにおける詳細な設計内容 について説明する.

\section{$2 \cdot 1$ 基本設計 : 錯覚誘発部位の選定と装置構成}

ニューロリハビリテーションで行われる訓練の一つに， ロボットやマニピュレータを活用した運動機能訓練が ある.これまでに様々な運動機能訓練用のリハビリテーションシステムが開発されてきているが，その多くは上 肢や下肢といった粗大運動機能訓練を行うものがほとんどであった. 一方, 手・指を対象とした巧緻運動機能訓 練が行えるリハビリテーションシステムについても近年開発が進められているが (川嵪他, 2006), 手・指の複雑 な動きを再現させるために大掛かりなシステム構成となってしまっている. 手・指の巧緻運動機能の回復には長 


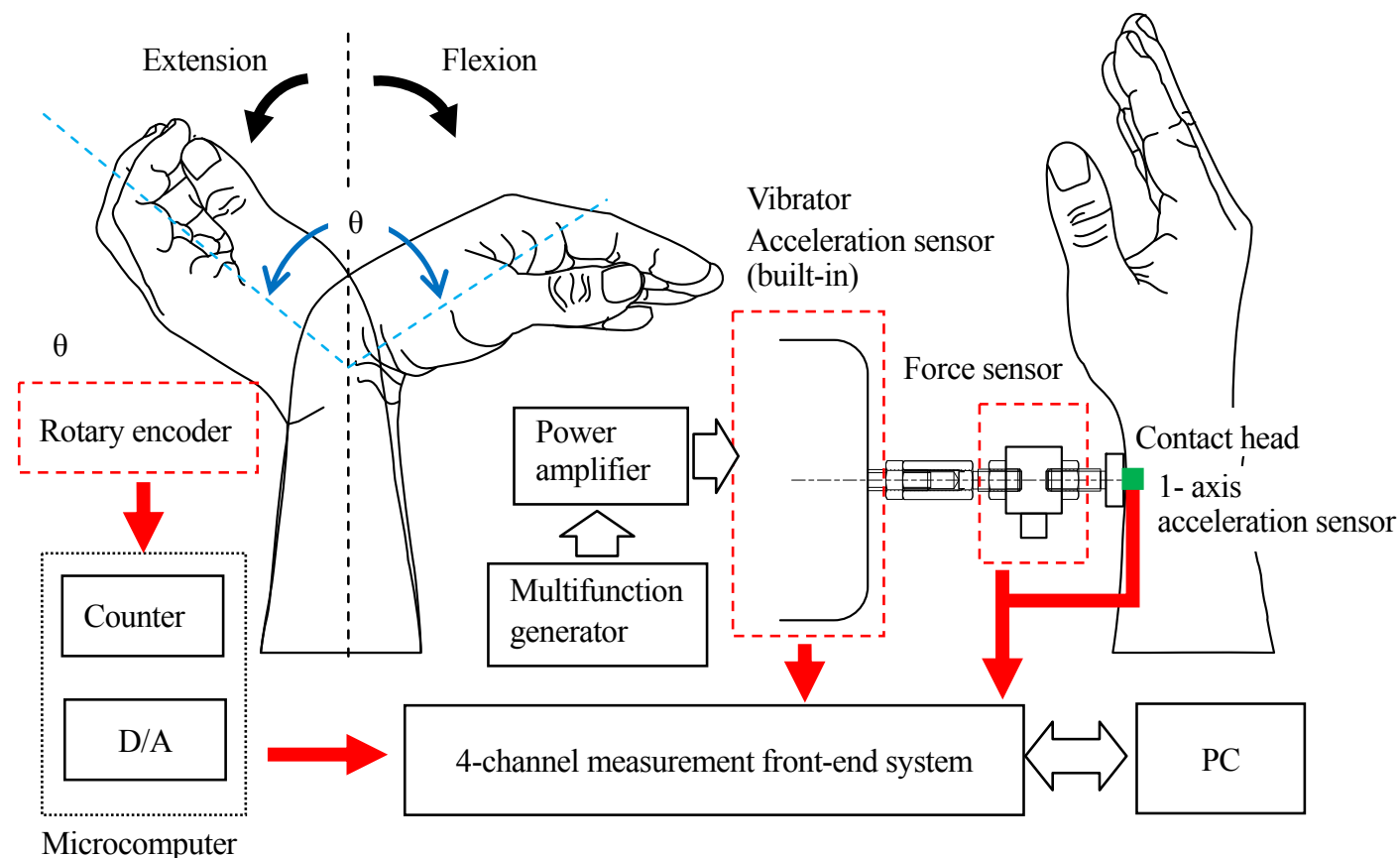

Fig. 1 System configuration of the desktop inducing and evaluation system of kinesthetic illusion. The right-hand side is a vibratory stimulation presentation part. The left-hand side is a joint angle - measuring part.

い年月がかかるとされており, 繰り返しの訓練が必要となる，そのため，一人で手軽に行えるリハビリテーショ ンシステムの実現が望まれている.

巧緻運動には手や指の関節運動が重要になるが, 本研究では, 浅層に関連筋が多く存在し，体表からそれら筋 腱を比較的容易刺激できる，手関節を錯覚誘発部位として選定した。

本節では，右手手関節の屈曲・伸展運動錯覚の誘発と，錯覚時に知覚する運動の記録が行える，卓上型運動錯 覚誘発・評価装置を提案する。ここで手関節とは，橈骨手根関節と手根間関節を総称した呼び名で手首の関節を 指寸.

提案した卓上型運動錯覚誘発・評価装置の制御・計測ブロック図を含んだ装置概要図を, 図 1 に示す．提案装 置は，手関節屈筋群や伸筋群の腱に振動刺激を与え伸展および屈曲運動の錯覚を誘起させる，右手側の振動刺激 提示部と, 錯覚誘発時に生じる右手手関節の屈曲・伸展方向の運動（動きの方向や角度）を実際の動きで再現さ せる, 左手側の運動錯覚量計測部から構成することとした.

提示させる振動刺激は定常振動のみとし, 装置構成を単純にするためフィードバック機構は設けず, 信号発生 器で刺激信号を生成する仕様とした。また，時間同期のとれた振動刺激量のモニタリングをリアルタイムで行え るように, 各種センサからの信号は計測フロントエンドで一括して受ける仕様とした.

\section{$2 \cdot 2$ 詳細設計 : 装置デザイン}

運動錯覚を誘発させるためには，対象部位を完全にリラックスさせることが重要だとされている(Naito, et al., 1999). 本研究で対象としている手関節は, 運動自由度が 2 であり, 掌屈 (屈曲) と背屈 (伸展), 橈屈 (外転) と尺屈 (内転) およびそれらを総合した分回し運動が可能である. また, 屈曲・伸展に約 $85 \mathrm{deg}$, 橈屈に約 $25 \mathrm{deg}$, 尺屈に約 $55 \mathrm{deg}$ の可動域を有している. そこで本研究開発では, 対象者が自然な姿勢・状態で振動刺激を受けら れるように, これら手関節の解剖学的な知見を考慮した, ユーザ中心設計の考えに基づいて装置をデザインした.

その結果，基本姿勢として左右の前腕を机上においた座位姿勢を採用することとした．両前腕部については， 机上に自然な形で腕を置いた時の姿勢を実現できるように, 手関節を $30 \mathrm{deg}$ 尺屈位, 时関節を $106 \mathrm{deg}$ から $110 \mathrm{deg}$ 屈曲位, 前腕を半回内位の状態で固定できるようなアームレスト部をデザインし，アームレスト先端に取り付け た把持棒を握ることで, 前腕の各関節を規定の角度で固定できるようにした. 振動刺激提示部のアームレスト先 端は, 手関節の運動を完全に拘束できるように可動機構は設けなかった。ただし, 運動錯覚量計測部のアームレ 
(a)

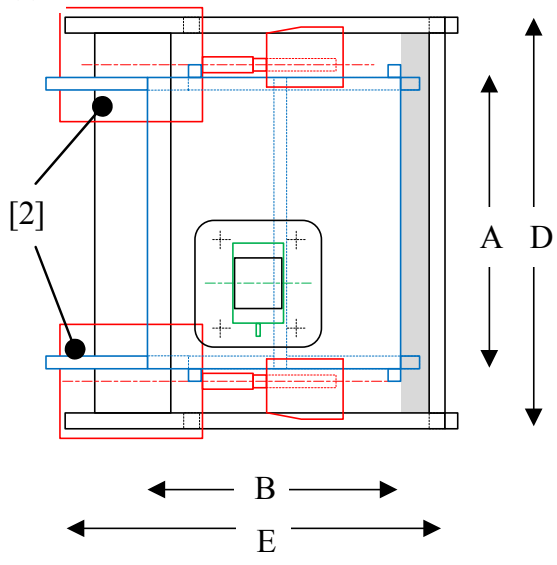

(b)

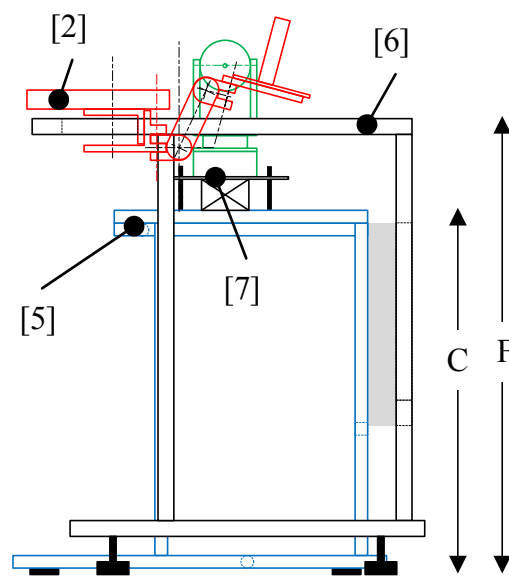

Table 1 Parts list.

\begin{tabular}{c|c}
\hline \hline Part & Name \\
\hline$[1]$ & Vibrator \\
\hline$[2]$ & Arm rest \\
\hline$[3]$ & Grip bar \\
\hline$[4]$ & Polyurethane sheet \\
\hline$[5]$ & Vibrator base \\
\hline$[6]$ & Arm rest base \\
\hline$[7]$ & $X, Y, Z$ precision stage \\
\hline
\end{tabular}

Table 2 Parts dimension.

\begin{tabular}{c|c}
\hline Part & $\begin{array}{c}\text { Dimension } \\
{[\mathrm{mm}]}\end{array}$ \\
\hline $\mathrm{A}$ & 460 \\
\hline $\mathrm{B}$ & 400 \\
\hline $\mathrm{C}$ & 555 \\
\hline $\mathrm{D}$ & 600 \\
\hline $\mathrm{E}$ & 560 \\
\hline $\mathrm{F}$ & 720 \\
\hline
\end{tabular}

(c)

[1]

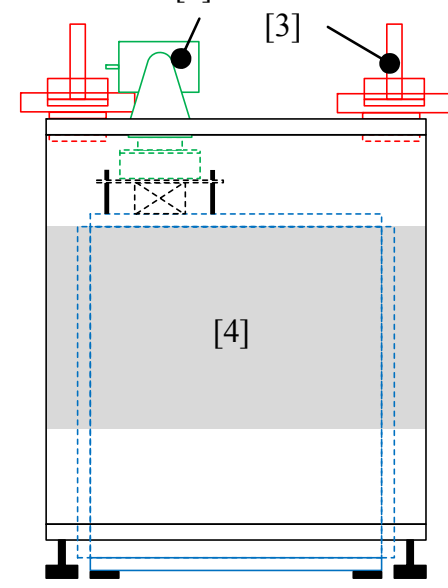

(d)

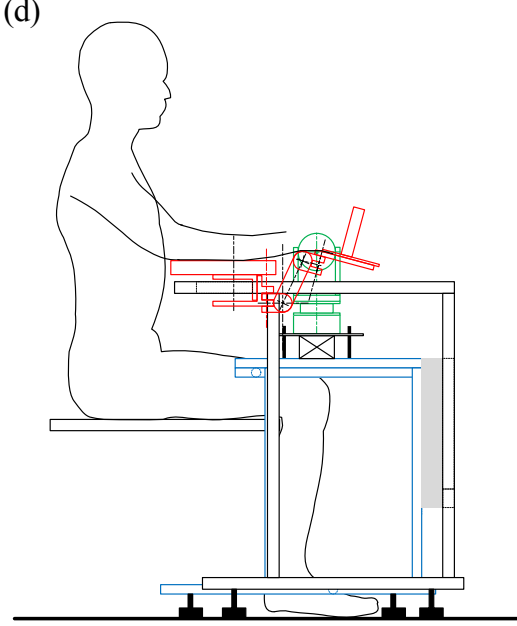

Fig. 2 Design of the desktop inducing and evaluation system of kinesthetic illusion. (a) Top view of the system. (b) Side view of the system. (c) Front view of the system. (d) Diagram showing when using the system.

スト先端は，右手手関節に生じる屈曲・伸展方向の運動錯覚を再現できるように，屈曲および伸展側に $90 \mathrm{deg} の$ 範囲で可動できる機構を採用した.

また，腱へ振動刺激を提示している最中，腱以外の部位に振動が伝わらないようにするため，振動提示デバイ スを配置するベース（加振機ベース）とアームレストを配置するベース（アームレストベース）を分離させたベ 一スセパレート型のデザインを採用した. 本開発装置の最終的なデザイン図と各部の寸法を図 2 , 表 1,2 に示す.

なお，装置各部の寸法は，人体寸法データベース (河内, 持丸, 2005) を参考に決定した.

\section{$2 \cdot 3$ 装置製作}

装置デザインを基に製作した卓上型運動錯覚誘発・評価装置と, 刺激が提示される手関節伸筋・屈筋群の腱を 図 3 に示寸. 図 3 (d) が振動刺激提示部, 図 3 (e) が運動錯覚量計測部である. 振動刺激は, 加振機ベースと, 振 動提示デバイスの加振機ベースへの取り付け位置を変えることで, 右手手関節屈筋群（橈側手根屈筋: FCR, 長掌 筋: PL，尺側手根屈筋: FCU）および右手手関節伸筋群（長橈側手根伸筋: ECRL，短橈側手根伸筋: ECRB，尺側手 根伸筋: ECU）の両方の腱に提示できる構造とした（図 3 は屈筋群への刺激提示を行う場合の装置構成).

振動刺激提示部の振動提示デバイスには, 加速度センサ内蔵の小型振動発生機 (EMIC Corp. 511-A) を使用し, パワーアンプ（EMIC Corp. 371-A）に接続されたマルチファンクションジェネレータ（NF Corp. WF1973）で信号 を生成することで，様々な振動刺激パターンの提示が行えるような構成とした. 小型振動発生機の可動部シャフ トには，力センサ（DYTRAN 1051V2）を介してステンレス製の円盤型接触子を先端に取り付けた. なお，接触 

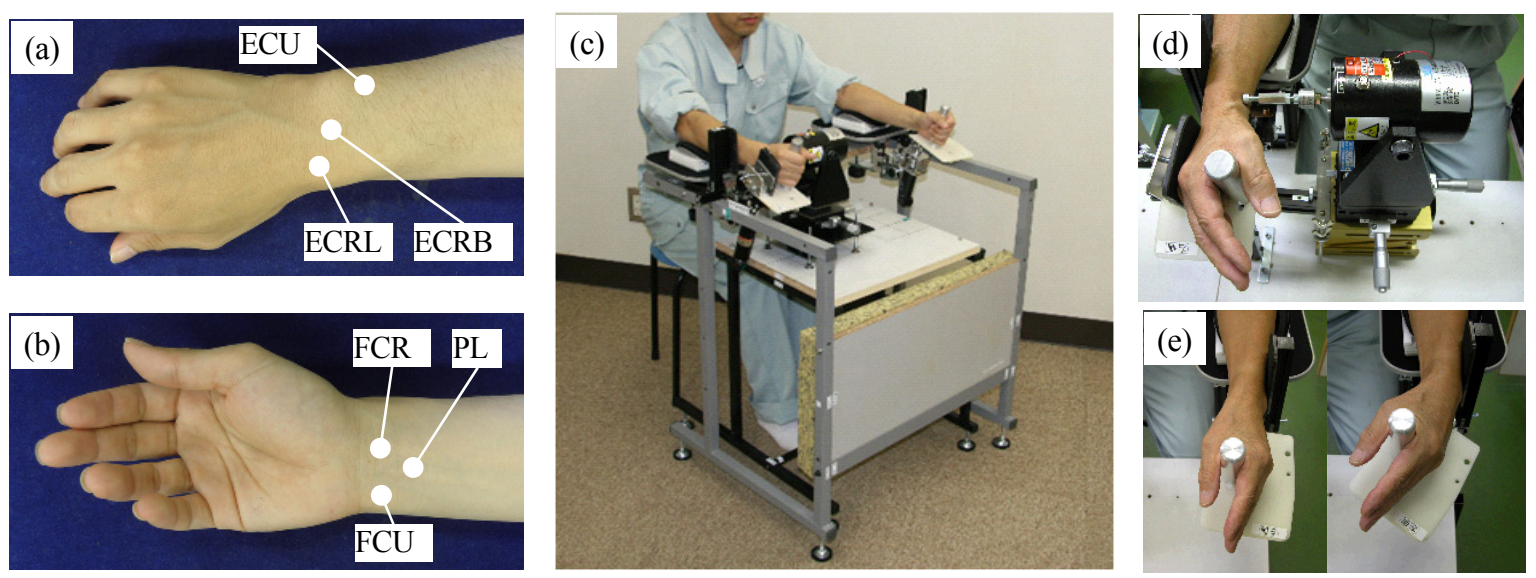

Fig. 3 (a) Wrist extensors. ECRL: Extensor carpi radialis longus. ECU: Extensor carpi ulnaris. ECRB: Extensor carpi radialis brevis. (b) Wrist flexors. FCR: Flexor carpi radialis. PL: Palmaris longus. FCU: Flexor carpi ulnaris. (c) Desktop inducing and evaluation system of kinesthetic illusion. (d) Vibratory stimulation presentation part. (e) Joint angle - measuring part.

子には 1 軸加速度センサ（ONO SOKKI. NP-2110: 0.6 g) を貼り付け, 先端の加速度も計測できるような構成とし た. また，小型振動発生機は，X，Y，Z方向への移動が行える精密ステージ（SIGMA KOKI）上に取付け，接触 子の腱への押し込み力や刺激ポイントへの正確な位置決めが行えるようにした．接触子は，力センサに直接接続 できる構造とし，接触子の大きさ（皮膚への接触面積の違い）による影響や複数の腱を同時に刺激した場合の影 響も調べられるように，先端径の異なる 5 種類（ $\Phi 5 ， 10 ， 15 ， 20 ， 25 ， 30 \mathrm{~mm} ）$ を用意した。 ここで，最小径と 最大径は，それぞれ痛みを生じない条件と複数の腱を同時に刺激できる条件から選定された，装置に取り付けら れているセンサ類は，全て計測フロントエンド（A\&D Company WCAmini）に入力され，時間同期の取れた状 態で，時間および周波数領域でのリアルタイム解析が行える仕様とした.

運動錯覚量計測部は，手関節可動部にロータリーエンコーダ（maxon motor HEDS-5540）を取り付け，伸展お よび屈曲運動の可動量（関節角度）を測定できる構成とした，ロータリーエンコーダの值はマイクロコンピュー タで角度に変換され， D/A 変換器を介して計測フロントエンドに入力される. 把持棒には温覚を刺激しないよう に，熱伝導率の小さいアクリル製丸棒を使用した．また，両ベースが接触する箇所には，加振機ベースからの振 動を遮断させる目的で $600 \times 320 \times 45 \mathrm{~mm}$ のチップウレタンフォームを間に設けた。

\section{3. 基本性能評価}

開発した装置の基本性能を明らかにするために性能評価実験を行う。本章ではまず始めに，本開発装置で採用 したベースセパレート型デザインの振動遮断効果を検証する. 続いて, 腱に提示可能な最大加速度特性を調べ, 開発装置で提示可能な最大振動刺激量を明らかにする.

なお，本章と次章で行ったヒトを対象とした実験では，本開発装置で刺激可能な 6 本の腱の内，皮膚上から腱 の形が確認できる FCR 腱を対象に実験を行った. またいずれの実験も, 前もって名古屋大学大学院情報科学研究 科の倫理委員会の承認を得るなど同研究科規定の手続きを経て実施した.

\section{$3 \cdot 1$ 振動遮断効果の検証実験}

腱へ振動刺激を提示するために振動提示デバイスを動作させると，その振動が様々な経路を経てアームレスト 部（特に前腕部）に伝わる.この伝播振動は錯覚の誘発を阻害する不要な振動である. 本装置では，このような 伝播振動を遮断する目的で，ベースセパレート型デザインを採用している．本節では，採用したデザインの有効 性を検証するために，振動提示デバイスを動作させた時のアームレストベース部の振動状態を調べる. 


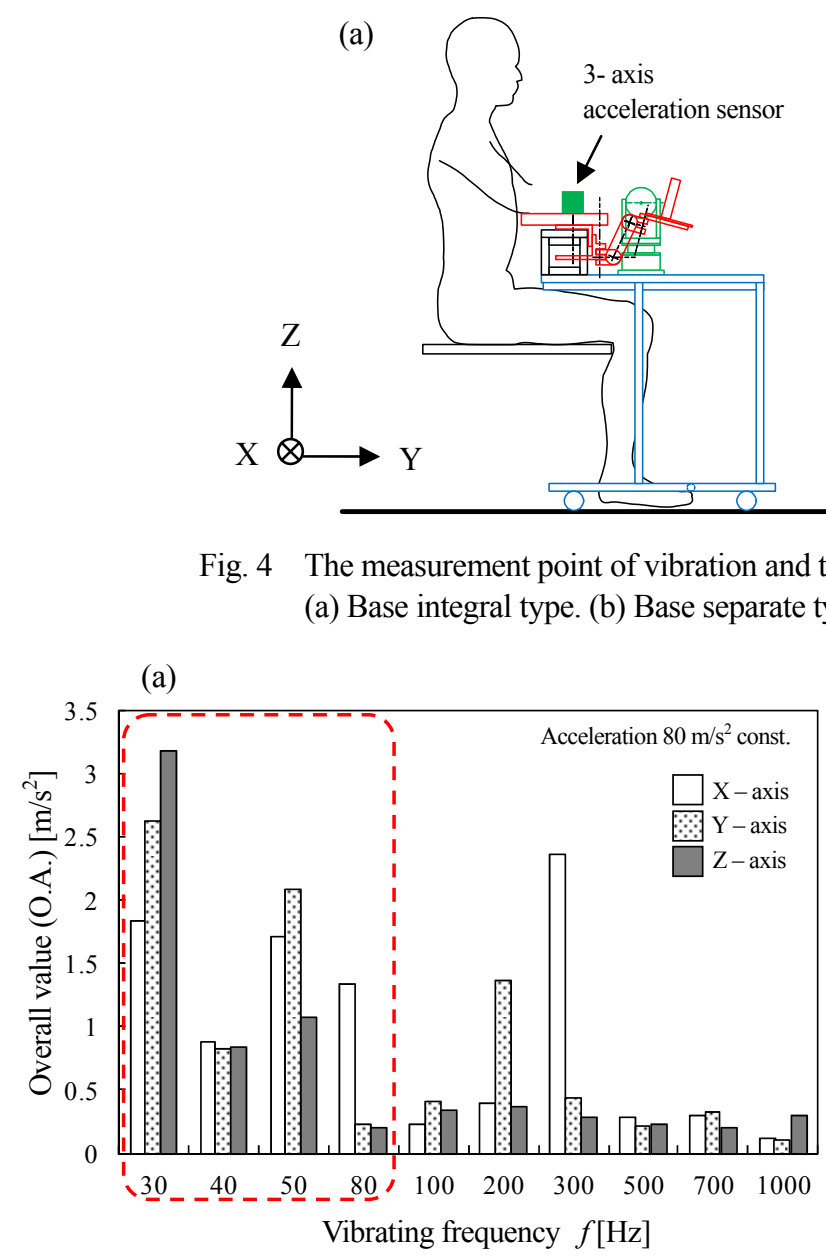

(b)

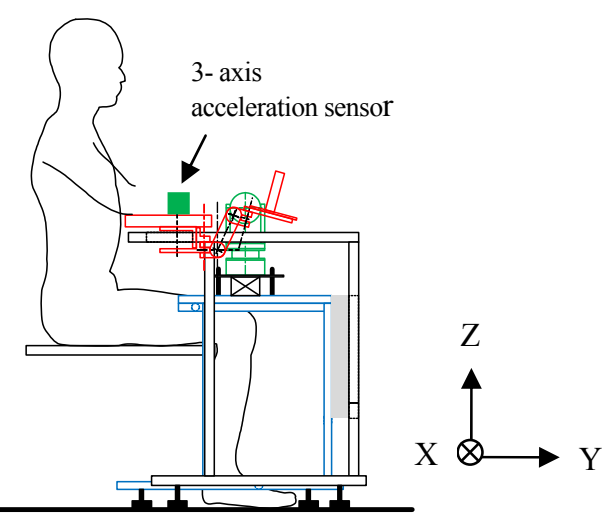

Fig. 4 The measurement point of vibration and the X-Y-Z coordinate system of acceleration sensor.

(a) (b)

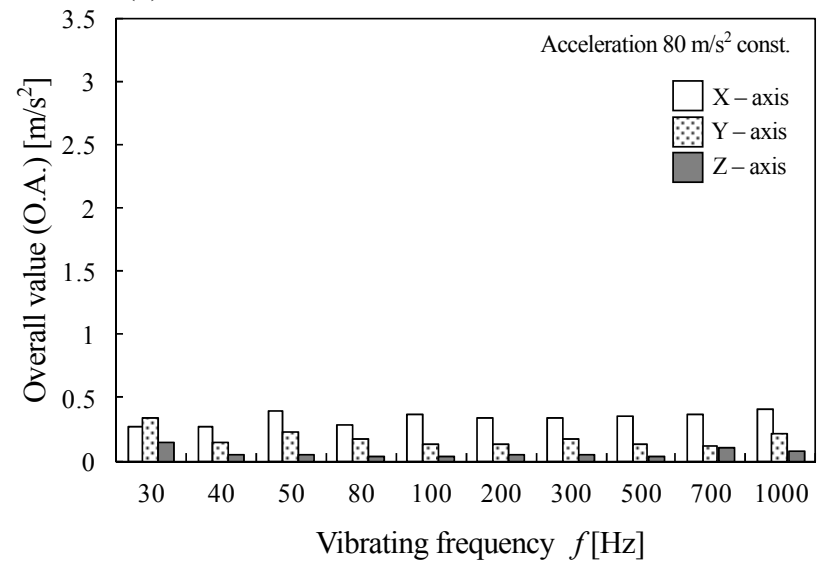

Fig. 5 The O.A. value of arm rest part when the vibratory stimulation device is running. (a) The result of the base integral type. Inside of a red dotted line perceives an unpleasant vibration. (b) The result of the base separate type.

\section{$3 \cdot 1 \cdot 1$ 実験方法}

開発装置の加振機ベースに取り付けられた振動刺激デバイスを，10 種類の周波数（30，40，50，80，100，200， $300,500,700,1000 \mathrm{~Hz}$ ) で $30 \mathrm{~s}$ 間加振させ, 各周波数時のアームレスト部の振動を 3 軸加速度センサ (ONO SOKKI NP3230: $4.55 \mathrm{~g}$ ) で計測した. なお，各周波数とも同じ加速度条件で実験が行えるように，実験加速度は，振動刺 激デバイスの $30 \mathrm{~Hz}$ 時の最大提示可能加速度に合わせ $80 \mathrm{~m} / \mathrm{s}^{2}$ とした. 加速度センサの值は $2.56 \mathrm{kHz}$ のサンプリン グ周波数で計測フロンエンドに取り込み, 分析周波数 $1 \mathrm{kHz}$, フレームサイズ 2048 の条件で FFT 解析し, 周波数 毎 X, Y, Z 方向の Overall (O.A.) 值を求めた.

また同様の実験を，振動提示デバイスとアームレストを同一ベース上に配置したベース一体型デザインの装置 についても行った. 両装置の 3 軸加速度センサの貼り付け位置とその座標系を図 4 に示す.

ここで O.A.值とは，全周波数スペクトルを合成したパワーで，時間領域のパワーに一致する值である.

\section{$3 \cdot 1 \cdot 2$ 実験結果および考察}

ベース一体型およびベースセパレート型運動錯覚誘発・評価装置における，振動提示デバイス動作時のアーム レスト部の O.A.值を図 5 に示す.

ベース一体型では，特に $80 \mathrm{~Hz}$ 以下の低周波領域で O.A.值が高くなっているのが見て取れる.これに対しべー スセパレート型では，全ての周波数条件で O.A.值が $0.5 \mathrm{~m} / \mathrm{s}^{2}$ を下回っており，振動提示デバイスからの不要な振 動を遮断できていることが確認できる. 実際にアームレスト部に前腕を置いた状態で加振実験を行ってみると， 


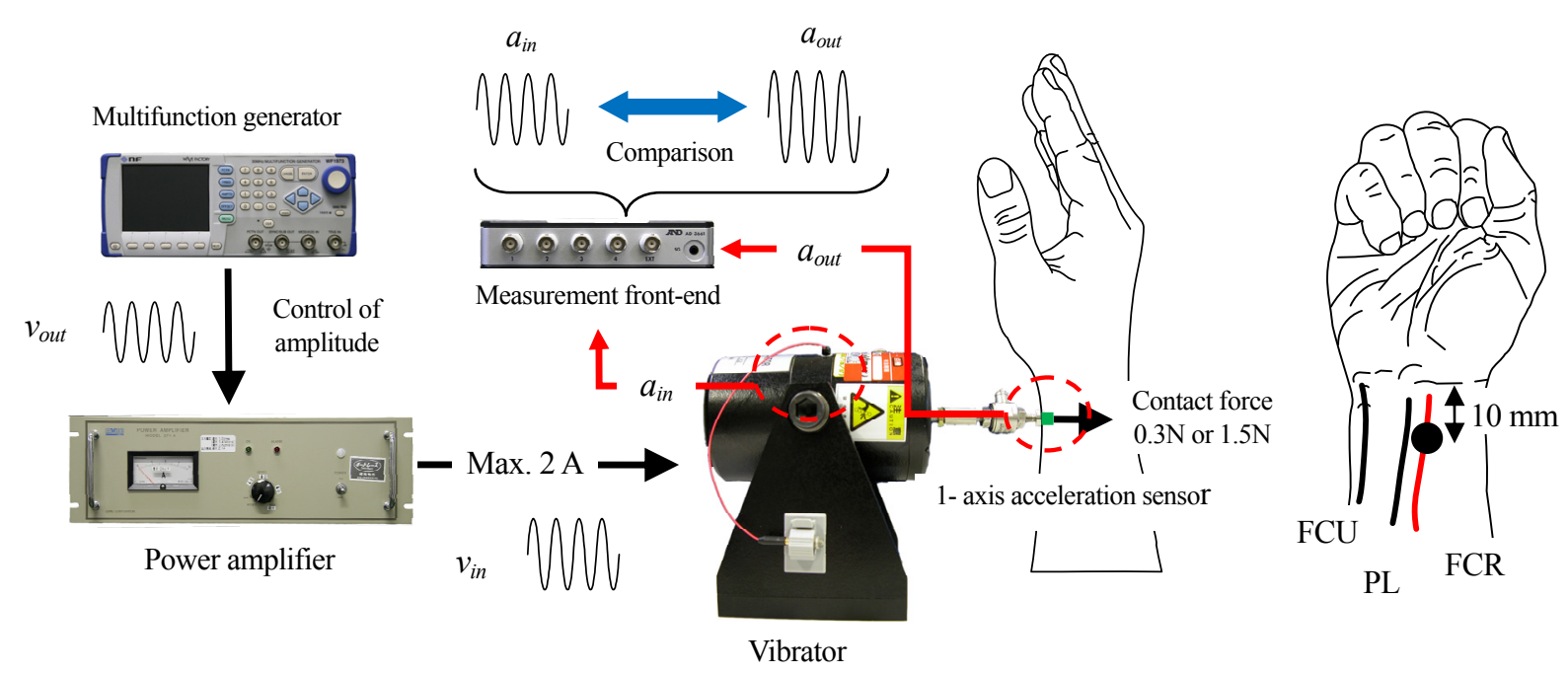

Fig. 6 Experimental set-up for measuring the maximum acceleration characteristic and the ratio of $a_{\text {out }}$ to $a_{\text {in }}$. The stimulus point on the tendon of wrist flexors.

ベース一体型装置では, 図 5 (a) の赤枠内の周波数 $(30 \mathrm{~Hz}$ から $80 \mathrm{~Hz})$ で不快な振動を知覚した. この領域は, 錯覚が誘発されやすい振動刺激周波数とされており, このような不快な振動は錯覚の誘発を阻害する要因となり うる. 一方，ベースセパレート型では，全ての周波数条件で不快な振動を知覚することは無かった.

以上本実験により，アームレスト部の振動を O.A.值で $0.5 \mathrm{~m} / \mathrm{s}^{2}$ 以下に抑えることができれば，加速度 $80 \mathrm{~m} / \mathrm{s}^{2}$ 程度の振動刺激であれば，不快な振動を知覚しないことが判明した．また，本開発装置で採用したベースセパレ 一ト型デザインでは，O.A.值を $0.5 \mathrm{~m} / \mathrm{s}^{2}$ 以下に抑えることができており，その振動遮断効果を確認することがで きた.

\section{$3 \cdot 2$ 腱へ提示可能な最大加速度特性}

振動刺激は，振動提示デバイス先端に取り付けた接触子を腱に押し込んだ状態で提示される．そのため，腱の 硬さや形状などが振動提示デバイスの負荷となり，振動提示デバイスの加振特性に影響を与える．そこで本節で は，実際にヒトの腱を加振させた時の，振動提示デバイスの最大提示加速度特性を調へ，開発装置で提示可能な 最大振動刺激量を明らかにする.

\section{$3 \cdot 2 \cdot 1$ 実験方法}

最大加速度特性を調べるための実験環境および測定に使用した腱（測定箇所）を図 6 に示す.

測定箇所は，実験参加者の右手掌から $10 \mathrm{~mm}$ 離れた橈側手根屈筋（FCR）腱上とし，同箇所に 1 軸加速度セン サ (ONO SOKKI NP-2110: $0.6 \mathrm{~g}$ ) を貼り付けた $\Phi 10 \mathrm{~mm}$ の接触子を, $0.3 \mathrm{~N}$ および $1.5 \mathrm{~N}$ の力で垂直に押し込んだ.

なお，皮膚上から観察できる FCR 腱の太さが $5 \sim 6 \mathrm{~mm}$ であることから，接触子については腱全体を刺激でき る最小径の接触子 $(\Phi 10 \mathrm{~mm})$ を使用した．刺激箇所は，全ての実験参加者間で同一箇所を刺激できるように手 掌と前腕の皮膚の境目を基準とし， $\Phi 10 \mathrm{~mm}$ の接触子が手掌に触れないよう，そこから $10 \mathrm{~mm}$ 前腕側に移動した FCR 腱上とした。また，押し込み力は予備実験により決定し，同箇所に接触子を押し込んだ時に痛みを感じない $2.1 \mathrm{~N}(0.7 \mathrm{~mm})$ 未満の力とした.

実験はそれぞれの押し込み力に対して行い, 振動提示デバイスを $20 \mathrm{~Hz}$ から $1000 \mathrm{~Hz}$ までの周波数で加振させ， $20 \mathrm{~Hz}$ から $100 \mathrm{~Hz}$ までは $10 \mathrm{~Hz}$ おきに，100 Hzから $240 \mathrm{~Hz}$ までは $20 \mathrm{~Hz}$ おきに，それ以降 $300 \mathrm{~Hz}, 500 \mathrm{~Hz}, 700$ $\mathrm{Hz}$ および $1000 \mathrm{~Hz}$ 時の，接触子先端と振動提示デバイス内部の最大提示加速度 $\left(a_{\text {out }}\right.$ および $\left.a_{i n}\right)$ を測定した.

最大提示加速度は，振動提示デバイスに最大定格電流を流した時に発生する加速度である. 今回使用した振動 提示デバイスの最大定格電流は $2 \mathrm{~A}$ であるため, 本実験では, 測定周波数毎振動提示デバイスに流れる電流が $2 \mathrm{~A}$ になるようにファンクションジェネレータの出力電圧 $\left(v_{\text {out }}\right)$ を調整し, この時発生する加速度を最大提示加速度 


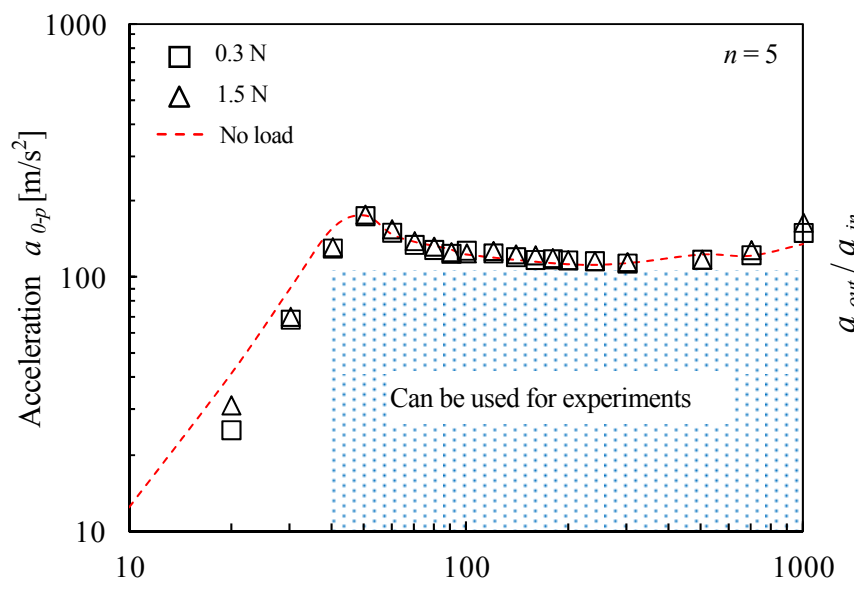

Frequency $f[\mathrm{~Hz}]$

Fig. 7 The maximum acceleration characteristic between the frequency 10 to $1000 \mathrm{~Hz}$.

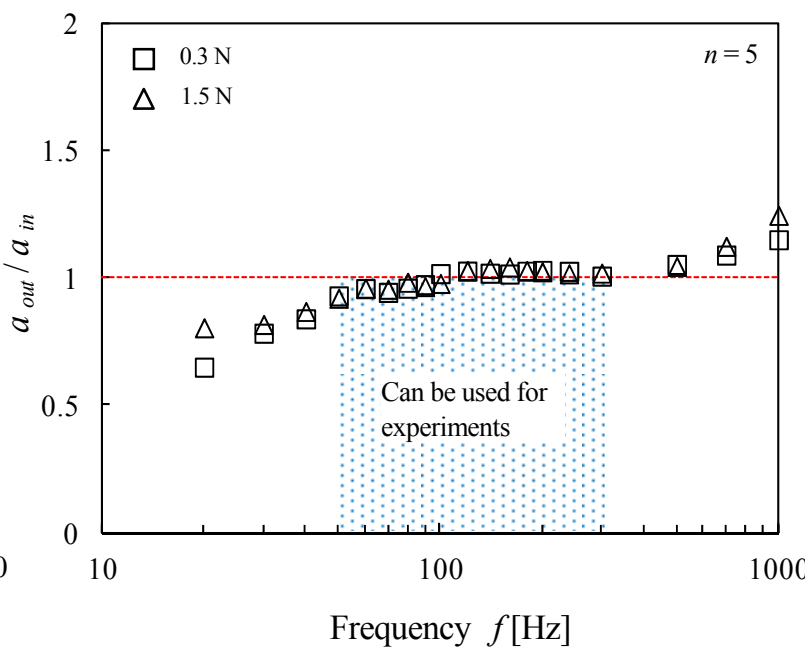

Fig. 8 The ratio of $a_{\text {out }}$ to $a_{\text {in }} . a_{\text {in }}$ is accelerations of the vibrator. $A_{\text {out }}$ is accelerations of a tip of contact head.

とした.ただし, $40 \mathrm{~Hz}$ 以下の周波数については, 振動提示デバイスに $2 \mathrm{~A} の$ 電流が流れる前に振幅制限 $(5 \mathrm{~mm}$ p-p $)$ に達してしまうため，振幅制限領域を超えない範囲での最大提示加速度を測定した.

接触子の押し込み力は，押し込み量を渦電流式変位センサ（KEYENCE EX-422V）で測定し，振動提示デバイ スの支持バネ定数から求めた．なお，支持バネ定数は実験前に錘（500 g と $250 \mathrm{~g} ）$ と渦電流式変位センサを用い て測定され $3.00 \mathrm{~N} / \mathrm{mm}$ であった.

\section{$3 \cdot 2 \cdot 2$ 実験結果および考察}

押し込み力 $0.3 \mathrm{~N}$ および $1.5 \mathrm{~N}$ 時の, $20 \mathrm{~Hz}$ から $1000 \mathrm{~Hz}$ までの接触子先端の最大加速度值 $a_{\text {out }}$ を図 7 に, 振動 提示デバイス内部の加速度 $a_{i n}$ に対する接触子先端の加速度 $a_{\text {out }}$ の比を図 8 に示寸. なお，いずれの值も実験参加 者 5 名の平均值である. また，図 7 赤点線は，無負荷時（何も接触させず加振させた時）の最大加速度特性を示 す. 図 7 より, 腱への押し込み力を増加させても最大加速度特性に変化は見られず, 無負荷時の最大加速度特性 とほぼ同じであることがわかった.このことから, 本開発装置では, 接触子の押し込み力が $1.5 \mathrm{~N}$ 以下であれば, $40 \mathrm{~Hz}$ 以上の周波数で最大 $100 \mathrm{~m} / \mathrm{s}^{2}$ の加速度を腱に提示可能であることが判明した. また, 図 8 の $a_{\text {in }}$ に対する $a_{\text {out }}$ の比をみてみると, $50 \mathrm{~Hz}$ から $300 \mathrm{~Hz}$ までの周波数で振動提示デバイス内部の加速度 $\left(a_{i n}\right)$ と接触子先端の加 速度 $\left(a_{\text {out }}\right)$ が同じであることがわかった。これは，この周波数範囲の振動刺激であれば，振動提示デバイス内部 の加速度をモニタリングすれば, 接触子先端に加速度センサを取り付けなくても接触子先端の加速度をモニタリ

ングできることを意味している.

以上，本実験で得られた結果をまとめると，本開発装置では，腱への押し込み力が $1.5 \mathrm{~N}$ 以下であれば， $50 \mathrm{~Hz}$ から $300 \mathrm{~Hz}$ までの周波数範囲で最大加速度 $100 \mathrm{~m} / \mathrm{s}^{2}$ の振動刺激を腱へ提示可能であり, その時の加速度值は振動 提示デバイス内部の加速度センサでモニタリングできることがわかった．この周波数範囲は，これまでの感覚情 報処理研究の中で用いられてきた, 運動錯覚を誘発させるための振動刺激周波数 $50 \mathrm{~Hz}$ から $100 \mathrm{~Hz}$ (Naito, et al., 1999), (Roll and Vedel, 1982) をカバーしており, 本開発装置が運動錯覚誘発・評価装置として十分な性能を有して いることがわかった.

\section{4. 運動錯覚誘発実験}

本章では, 知覚特性評価装置としての有効性を確かめるために, 適応的心理物理学的測定法の一つである階段 法 (Gescheider,1997) を用いて, 右手手関節伸展方向の運動錯覚を誘発させる必要最低限の刺激值 (誘発刺激閾) の推定を行う.また，同推定実験をとおして錯覚を誘発・制御させるための振動刺激条件の蓄積を図る. 
ここで階段法とは，閾值を測定するための心理物理学的測定法の一つである. 古典的心理物理学的測定法（恒 常法, 極限法, 調整法) に比心゙少ない試行数で閾值の推定が行えるため, 測定時間の短縮が図れるという利点が ある。

\section{$4 \cdot 1$ 実験方法}

上肢の感覚および運動に障害の無い 22 歳から 27 歳 (平均年齢 24.2 歳, 平均身長 $170.2 \pm 3.5 \mathrm{~cm}$, 平均体重 59.0 $\pm 5.1 \mathrm{~kg}$ ，利き手:右）の男性 5 名が実験に参加した，参加者には事前に実験内容の説明を行い，書面での同意を 得た上で実験に協力してもらった．また実験に先立ち，実験手順の確認と手関節伸展方向の運動錯覚を体験させ るために練習試行を設けた.

実験に用いた刺激系列および刺激パターンを図 9 に示す. 刺激は $0 \mathrm{~m} / \mathrm{s}^{2}$ から階段的に $10 \mathrm{~m} / \mathrm{s}^{2}$ ステップで増加さ せ，実験参加者の反応が変わったところ（反応遷移点 $\mathrm{P}_{1} \sim \mathrm{P}_{\mathrm{n}}$ ) で刺激值を記録し刺激系列の方向を上昇から下降 へ(もしくはその逆へ) 反転させた。 ただし一つ目の反応遷移点 $\mathrm{P}_{1}$ が得られた後は, 刺激の増減を $5 \mathrm{~m} / \mathrm{s}^{2}$ ステッ プ間隔とし，実験参加者の反応が変わるたびに刺激を反転させた．各ステップ間隔を 1 試行とし，反応遷移点が 5 個得られるまで試行を繰り返した。誘発刺激閾值は，得られた 5 個の反応遷移点の刺激值の平均とした．各試 行における刺激パターンは, $15 \mathrm{~s}$ 刺激を提示した後 $60 \mathrm{~s}$ の休秘を設ける形とした.

実験参加者にはアイマスクおよび耳栓を装着し，外部からの情報を遮断した状態で実験を行った．刺激は，3.2 節の実験と同様の箇所 (掌から $10 \mathrm{~mm}$ 離れた右手橈側手根屈筋 FCR 腱) に $\Phi 10 \mathrm{~mm}$ の接触子を $0.3 \mathrm{~N}$ おび $1.5 \mathrm{~N}$

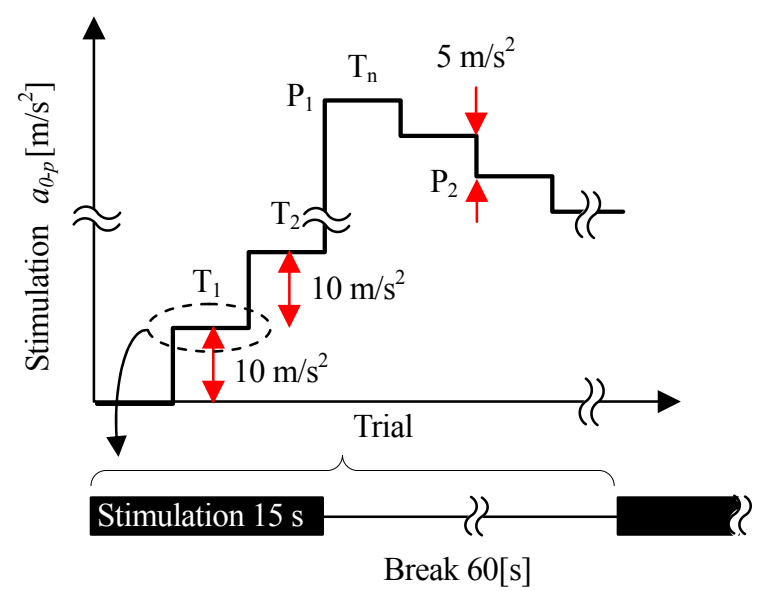

Fig. 9 Stimulation series and pattern of staircase method.

(a)

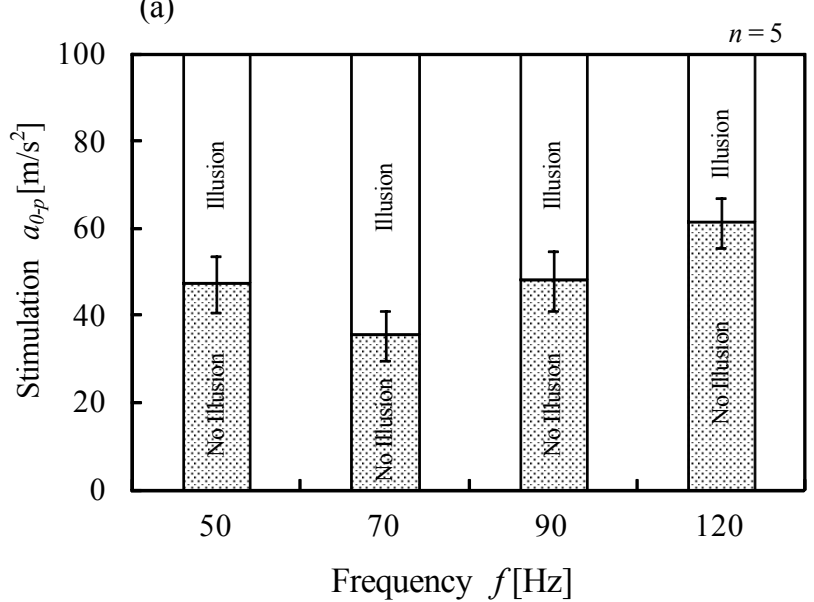

Table 3 Illusion inducement rate.

\begin{tabular}{|c|c|c|}
\hline \multirow{3}{*}{$\begin{array}{c}\text { Frequency } \\
\qquad[\mathrm{Hz}]\end{array}$} & \multicolumn{2}{|c|}{ Contact force } \\
\hline & $0.3[\mathrm{~N}]$ & $1.5[\mathrm{~N}]$ \\
\hline & $\begin{array}{c}\text { Inducement } \\
\text { rate[\%] }\end{array}$ & $\begin{array}{c}\text { Inducement } \\
\text { rate }[\%]\end{array}$ \\
\hline 50 & 100 & 100 \\
\hline 70 & 100 & 100 \\
\hline 90 & 100 & 100 \\
\hline 120 & 40 & 80 \\
\hline
\end{tabular}

(b)

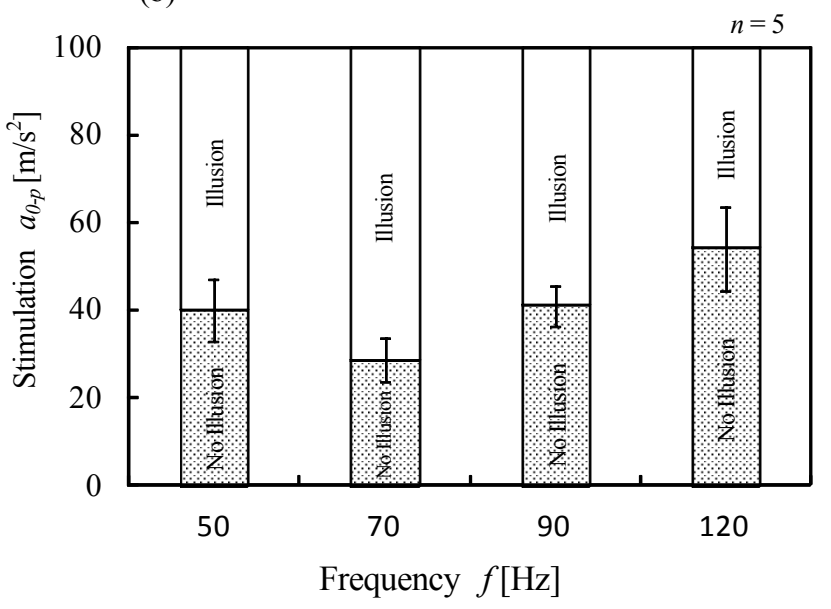

Fig. 10 The stimulation threshold on each frequency conditions. (a) Contact force $0.3 \mathrm{~N}$. (b) Contact force $1.5 \mathrm{~N}$. The result of One-way repeated measures ANOVA on each contact force conditions was $p<.05$, but the frequency is in $50 \mathrm{~Hz}$ to $90 \mathrm{~Hz}$. 
の力で垂直に押し込んだ状態で提示され，右手手関節伸展方向の錯覚を誘発させた．なお，押し込み力は，前章 の実験同様接触子の押し込み量を渦電流式変位センサ（KEYENCE EX-422V）で測定し，振動提示デバイスの支 持バネ定数から求めた.

実験は，周波数 4 条件 $(50 \mathrm{~Hz}, 70 \mathrm{~Hz}, 90 \mathrm{~Hz}, 120 \mathrm{~Hz}) \times$ 押し込み力 2 条件 $(0.3 \mathrm{~N}, 1.5 \mathrm{~N})$ の計 8 条件につ いて行い，それぞれの条件下での誘発刺激閾值を推定した．実験参加者には，試行毎の休息中に錯覚が誘発され たかどうかの回答を求めた。回答は，錯覚が誘発されていれば開発装置の運動錯覚量計測部でその方向を再現し てもらい，錯覚が誘発されていなければ口頭でその旨を伝えてもらった．なお，屈曲方向へ再現した回答は『運 動錯覚の誘発なし』とした.

\section{$4 \cdot 2$ 実験結果および考察}

押し込み力 $0.3 \mathrm{~N}$ および $1.5 \mathrm{~N}$, 振動刺激周波数 $50 \mathrm{~Hz}, 70 \mathrm{~Hz}, 90 \mathrm{~Hz}$ および $120 \mathrm{~Hz}$ 時の 5 名の誘発刺激閾值 (加 速度）の平均と標準誤差を図 10 に, 錯覚誘発率を表 3 に示寸.

2 種類の押し込み力とも， $50 \mathrm{~Hz}, 70 \mathrm{~Hz}, 90 \mathrm{~Hz}$ の振動刺激で実験参加者全員に錯覚が誘発された（錯覚誘発率 $100 \%$ ）。ただし $120 \mathrm{~Hz}$ の振動刺激では，押し込み力 $0.3 \mathrm{~N}$ で 3 名（錯覚誘発率 $40 \%$ ），1.5 N で 1 名（錯覚誘発 率 $80 \%$ ）の実験参加者に錯覚が誘発されなかった。 また， $70 \mathrm{~Hz}$ の振動刺激で最小の誘発刺激閾值を示し，その 值は, 押し込み力 $0.3 \mathrm{~N}$ で約 $40 \mathrm{~m} / \mathrm{s}^{2}, 1.5 \mathrm{~N}$ で約 $30 \mathrm{~m} / \mathrm{s}^{2}$ であった。 そこで, 刺激閾值に対する周波数の効果を検 証するために, 錯覚誘発率 $100 \%$ \% $50 \mathrm{~Hz}, 70 \mathrm{~Hz}, 90 \mathrm{~Hz}$ の刺激閾值に対して, 周波数を要因とした反復 1 元配 置分散分析を行った. その結果，2 種類の押し込み力とも周波数の効果に有意差が認められ $(0.3 \mathrm{~N}:[F(2,8)=$ $4.499 p<.05], 1.5 \mathrm{~N}:[F(2,8)=6.418 p<.05])$, 周波数によって刺激閾值が変化することが確認できた. ただ し, 下位検定として行った Bonferroni の多重比較では, 両押し込み力とも, 全ての周波数群間で有意差は認めら れなかった. 以上統計解析の結果を踏まえると, 周波数は刺激閾值の変化に寄与するが，その効果は周波数群間 に差が認められるほど大きいものでないことがわかった. よって, $50 \mathrm{~Hz}$ から $90 \mathrm{~Hz}$ の振動刺激では, $40 \mathrm{~m} / \mathrm{s}^{2}$ 付 近にほぼ一定の刺激閾值が存在していると推測される. なお, 本実験を通して, 2 種類の押し込み力の間で知覚 する錯覚の鮮明さに違いが生ずるということが明らかになりつつあるが，現段階では定性的な傾向に留まってい る. 今後, 周波数や押し込み力などの違いによる錯覚知覚特性の変化を詳細に調べることで, 差異を定量的に明 らかにしていく予定である.

運動錯覚は，腱に振動刺激を与えても誘発されない時もあり，また，不明瞭である場合も多いとされている (Collins and Prochazka, 1996), (矢口他, 2009)。これに対して, 本開発装置を用いた錯覚誘発実験では, 上述のとお り全ての実験参加者に運動錯覚が誘発された。このことは，適切にデザインされた装置と振動刺激条件を用いれ ば，運動錯覚は比較的容易に誘発できることを示唆している．本実験では，手掌から $10 \mathrm{~mm}$ 離れた FCR 腱上に $\Phi 10 \mathrm{~mm}$ の接触子を $0.3 \mathrm{~N}$ または $1.5 \mathrm{~N}$ の力で押し込んだ場合, $50 \mathrm{~Hz}$ から $90 \mathrm{~Hz}$ の振動刺激では, 約 $40 \mathrm{~m} / \mathrm{s}^{2}$ 以上 の加速度で腱を刺激することで, 手関節伸展方向の運動錯覚を誘発させられることを明らかにした。

\section{5. 結 言}

我々の最終目標は，麻痺肢の腱上の皮膚に小型振動提示デバイスを貼り付けるだけで運動機能訓練が行える， 運動錯覚現象を応用したシンプルかつ安価なリハビリテーションシステムの実現とその臨床応用である. このよ うなリハビリテーションシステムを実現させるためには，運動錯覚現象の自在な誘発と制御を可能とする振動刺 激条件の確立と体系化が必要不可欠であり, 同現象の知覚特性を詳細に調心゙上げる必要がある. そこで本研究で は, これら知覚特性を調べるうえで必要となる, 振動刺激量の制御とモニタリングが可能な卓上型運動錯覚誘発・ 評価装置の開発を行い, 健常者の手関節伸展運動の錯覚を誘発させるための刺激閾值を推定することで, 知覚特 性評価装置としての有効性の確認と錯覚を誘発・制御させるための振動刺激条件の蓄積を図ることを目的とした.

本稿では, 卓上型運動錯覚誘発・評価装置を実現させるための一連の設計手順について述べ, 開発装置の基本 性能評価実験をとおして同装置の基本スペックを明らかにした。その結果本開発装置では, 腱への押し込み力が $1.5 \mathrm{~N}$ 以下であれば, $50 \mathrm{~Hz}$ から $300 \mathrm{~Hz}$ までの周波数範囲で最大 $100 \mathrm{~m} / \mathrm{s}^{2}$ の振動刺激を腱に提示でき，この周波数 範囲内であれば，腱にかかる実加速度を振動提示デバイス内部の加速度センサでモニタリングできることを明ら 
かにした．また，本開発装置を使い，5名の実験参加者に対して FCR 腱を単独刺激した時の手関節伸展方向の運 動錯覚誘発実験を行った. その結果, 加速度 $40 \mathrm{~m} / \mathrm{s}^{2}$ 以上の $50 \mathrm{~Hz}$ から $90 \mathrm{~Hz}$ の振動刺激で, 全ての実験参加者に 運動錯覚の誘発が確認され, 本開発装置の知覚特性評価装置としての有効性と FCR 腱を単独刺激した時の錯覚誘 発刺激閾值を明らかにした。

脳卒中片麻㿁患者に対する運動機能訓練では, 麻痺肢に対して罹患前の正常な動きを繰り返し再現させる必要 がある，そのため，健常者で得られたこれら刺激条件は，運動錯覚を応用した運動機能訓練において，患者に正 常な動きを錯覚で再現させるための重要な基本条件となる.

今後は, 本研究で得られた刺激条件を基に, 同じく FCR 腱を単独刺激した時の, 周波数や押し込み力などの違 いによる錯覚知覚特性（実験参加者が知覚する錯覚の鮮明さや動きの角度や速度といった感覚量）の変化を調べ るとともに, FCR 腱以外の屈筋腱や伸筋腱についても同様の実験を行い, 各腱を単独刺激した場合の知覚特性を 明らかにしていく。しかしながら，健常者のみの実験では十分ではないために，健常者での刺激条件がある程度 蓄積された段階で, 脳卒中片麻痺患者に対する錯覚誘発実験を行うことを予定している. 以上の実験で得られた 実験データに基づいて, 手関節運動機能訓練への応用可能性を探っていく. そのために, 錯覚肢の運動の有無（鮮 明さ）と運動（関節角度や運動速度）の両方を知覚させるための条件について研究を進めていく予定である.

\section{謝 辞 \\ 本研究の一部は, JSPS 科研費基盤研究 (B) 26282164, j6282164 の助成を受けた.}

\section{文献}

Collins, D. F. and Prochazka, A., Movement illusions evoked by ensemble cutaneous input from the dorsum of the human hand, The Journal of physiology, 496 (Pt 3) (1996), pp.857-871.

Fujiwara, T., Kasashima, Y., Honaga, K., Muraoka, Y., Tsuji, T., Osu, R., Hase, K., Masakado, Y. and Liu, M., Motor improvement and corticospinal modulation induced by hybrid assistive neuromuscular dynamic stimulation (HANDS) therapy in patients with chronic stroke, Neurorehabil Neural Repair, 23 (2009), pp.25-132.

Gescheider, G. A., Psychophysics, Lawrence Erlbaum (1997) (宮岡徹 監訳, 心理物理学方法・理論・応用<上巻>, 北大 路書房, 2002, pp.48-50.)

Goodwin, G. M., McCloskey, D. I. and Matthews, P. B., Proprioceptive illusions induced by muscle vibration: contribution by muscle spindles to perception?, Science, 175 (1972), pp. 1382-1384.

原寛美, 脳卒中運動麻痺回復可塑性理論とステージ理論に依拠したリハビリテーション(<特集>ニューロリハビ リテーションの進歩), 脳神経外科ジャーナル, 21(7)(2012), pp.516-526.

Kawahira, K., Shimodozono, M., Ogata, A. and Tanaka, N., Addition of intensive repetition of facilitation exercise to multidisciplinary rehabilitation promotes motor functional recovery of the hemiplegic lower limb, Journal of Rehabilitation Medicine, 36 (4) (2004), pp.159-164.

川㠃晴久, 木村宏樹, 伊藤聡, 西本裕, 林浩之, 栄枝裕文, 手指リハビリテーション支援システムの研究 (第 1 報 概念と 1 例試験報告)，日本機械学会論文 C 編, Vol. 72, No. 720 (2006), pp. $228-233$.

河内まき子，持丸正明, AIST 人体寸法データベース, 産業技術総合研究所 (2005), H16PRO 287.

厚生 労働省, 平成 24 年 (2012) 人口動態統計 (確定数) の概 況, 厚生労働省, $<$ http://www.mhlw.go.jp/toukei/saikin/hw/jinkou/kakutei12/index.html>, (参照日 2014 年 6 月 6 日).

厚 生 労 働 省, 平成 23 年 (2011) 患者調査の概況, 厚生労働省, $<$ http://www.mhlw.go.jp/toukei/saikin/hw/kanja/11/index.html>, (参照日 2014 年 6 月 6 日).

Naito, E., Ehrsson, H. H., Geyer, S., Zilles, K. and Roland, P. E., Illusory arm movements activate cortical motor areas: a positron emission tomography study, The Journal of neuroscience, 19 (14) (1999), pp.6134-6144.

Roll, J. P. and Vedel, J. P., Kinaesthetic role of muscle afferents in man, studied by tendon vibration and microneurography, Experimental Brain Research, 47 (2) (1982), pp.177-190.

Wolf, S. L., Lecraw, D. E., Barton, L. A. and Jann, B. B., Forced use of hemiplegic upper extremities to reverse the effect of learned nonuse among chronic stroke and head-injured patients, Experimental neurology, 104 (2) (1989), pp.125-132.

湯川善裕, 富永孝紀, 河野正志, 谷口博, 森岡周, 脳卒中片麻痺患者における振動誘発運動感覚錯覚中の脳活動 
～機能的近赤外分光装置（fNIRS）研究～, 作業療法, 31 (2012), pp. 41-51.

矢口博彬, 深山理, 鈴木隆文, 満㴊邦彦, 腱振動刺激により生成される運動感覚の明瞭化のための刺激条件の検 討, BPES 2009 第 24 回生体・生理工学シンポジウム論文集, 2A1-05 (2009), pp.167-168.

\section{References}

Collins, D. F. and Prochazka, A., Movement illusions evoked by ensemble cutaneous input from the dorsum of the human hand, The Journal of physiology, 496 (Pt 3) (1996), pp.857-871.

Fujiwara, T., Kasashima, Y., Honaga, K., Muraoka, Y., Tsuji, T., Osu, R., Hase, K., Masakado, Y. and Liu, M., Motor improvement and corticospinal modulation induced by hybrid assistive neuromuscular dynamic stimulation (HANDS) therapy in patients with chronic stroke, Neurorehabil Neural Repair, 23 (2009), pp.25-132.

Gescheider, G. A., Psychophysics, Lawrence Erlbaum (1997), pp.59-62.

Goodwin, G. M., McCloskey, D. I. and Matthews, P. B., Proprioceptive illusions induced by muscle vibration: contribution by muscle spindles to perception?, Science, 175 (1972), pp. 1382-1384.

Hara, H., Stroke rehabilitation based on cortical plasticity and the stage theory of motor output reorganization ( $<$ SPECIAL ISSUE>Development of neuro-rehabilitation), Japanese Journal of Neurosurgery, 21(7) (2012), pp.516 - 526 (in Japanese).

Kawahira, K., Shimodozono, M., Ogata, A. and Tanaka, N., Addition of intensive repetition of facilitation exercise to multidisciplinary rehabilitation promotes motor functional recovery of the hemiplegic lower limb, Journal of Rehabilitation Medicine, 36 (4) (2004), pp.159-164.

Kawasaki, H., Kimura, H., Ito, S., Nishimoto, Y., Hayashi, H. and Sakaeda, H., Hand rehabilitation support system : 1st report, concept and preliminary test, Transactions of the Japan Society of Mechanical Engineers, Series C, Vol.72, No.720 (2006), pp.228-233 (in Japanese).

Kouchi, M. and Mochimaru, M., AIST Anthropometric database, National Institute of Advanced Industrial Science and Technology (2005), H16PRO 287 (in Japanese).

Ministry of Health, Labour and Welfare (2012) Vital statistics of japan (Final data), Ministry of Health, Labour and Welfare, available from <http://www.mhlw.go.jp/toukei/saikin/hw/jinkou/kakutei12/index.html>, (accessed on 6 June, 2014) (in Japanese).

Ministry of Health, Labour and Welfare (2011) Patient survey, Ministry of Health, Labour and Welfare, available from $<$ http://www.mhlw.go.jp/toukei/saikin/hw/jinkou/kakutei12/index.html>, (accessed on 6 June, 2014) (in Japanese).

Naito, E., Ehrsson, H. H., Geyer, S., Zilles, K. and Roland, P. E., Illusory arm movements activate cortical motor areas: a positron emission tomography study, The Journal of neuroscience, 19 (14) (1999), pp.6134-6144.

Roll, J. P. and Vedel, J. P., Kinaesthetic role of muscle afferents in man, studied by tendon vibration and microneurography, Experimental Brain Research, 47 (2) (1982), pp.177-190.

Wolf, S. L., Lecraw, D. E., Barton, L. A. and Jann, B. B., Forced use of hemiplegic upper extremities to reverse the effect of learned nonuse among chronic stroke and head-injured patients, Experimental neurology, 104 (2) (1989), pp.125-132.

Yukawa, Y., Tominaga, T., Kono, M., Taniguchi, H. and Morioka, S., Brain activity during vibration-induced illusory movements in hemiplegic stroke patients, The Journal of Japanese Occupational Therapy Association, 31(1) (2012), pp.41-51 (in Japanese).

Yaguchi, H., Fukayama, O., Suzuki, T. and Mabuchi, K., A study of stimulus condition for clear proprioception generated by tendon vibration, Proceedings of the 24th Symposium on Biological and Physiological Engineering (BPES2009), 2A1-05 (2009), pp.167-168 (in Japanese). 